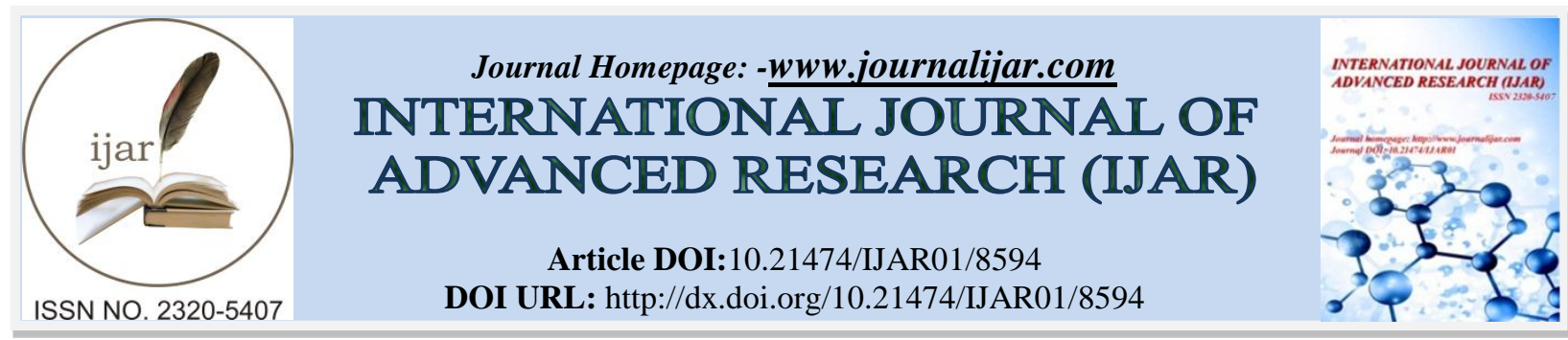

RESEARCH ARTICLE

\title{
SEASONAL VARIATIONS IN NUTRIENT CONCENTRATION OF JUICE AND SKIN OF TEN GRAPE (VITIS VINIFERA L.) GENOTYPES.
}

\author{
Shafia Bashir ${ }^{1 *}$, Nirmaljit Kaur ${ }^{1}$ PPS Gill ${ }^{2}$ and N.K Arora ${ }^{2}$. \\ 1. Department of Botany, Punjab Agricultural University, Ludhiana-141004, India. \\ 2. Department of Fruit Science, Punjab Agricultural University, Ludhiana-141004, India.
}

\section{Manuscript Info}

Manuscript History

Received: 02 January 2018

Final Accepted: 04 February 2019

Published: March 2019

Key words:-

berry development; calcium; grapes; nitrogen; potassium.

\section{Abstract}

The nutrient status of grape berries is not only of interest to the viticulturists but also to oenologists because of their impact on juice nutritional value. The aim of the study was to determine the total potassium, total calcium and nitrogen in the berry skin and juice of ten grape genotypes grown in northwestern India. The total potassium, calcium and nitrogen content in the grape genotypes varied significantly in berry skin, juice and evaluation years. Among the grape genotypes maximum calcium was recorded in Punjab MACS Purple in skin $(0.497 \mathrm{mg} / \mathrm{l})$ and juice $(0.403 \mathrm{mg} / \mathrm{l})$ at ripened stage. The maximum potassium was also at ripened stage in the skin of $\mathrm{H}$ $27(2.800 \%)$ and juice of Perlette ( $1.610 \%)$. However, nitrogen content was maximum in the skin of Merlot $(0.336 \mathrm{mg} / \mathrm{l})$ and juice of Perlette( $0.184 \%$ ) at green stage. This study suggests that the selected grape genotypes are the potential sources of essential mineral nutrients.

Copy Right, IJAR, 2019,. All rights reserved.

\section{Introduction:-}

Grape berry development is associated with an influx of water, carbon and a number of mineral elements. The mineral nutrient concentration in grapes changes throughout the growing season. Atleast 17 elements are considered essential for the growth and development of plants, with some having a role in the structure of compounds while others are involved in enzyme activation, or as a charge carrier and osmoregulator. They usually make up approximately 0.2 to $0.6 \%$ of the fresh weight of the fruit. The important mineral compounds in the grape berries include potassium, calcium, iron, phosphates, sulphate and chloride which have influence on the nutritional value of the grape juice and wine. The mineral composition of the grapes influence the quality and organoleptic properties of wine. Essential elements are classified as high phloem mobility (magnesium, phosphorus, potassium and sulphur), low phloem mobility (calcium and manganese) and variable and conditional phloem mobility (boron, copper, iron and zinc) (Welch 1986 ). Elements that have low mobility in the phloem can be transported via the xylem. The accumulation of phloem and xylem mobile elements into the tissue are essential in the vascular stream for the development of tissues. For example, berry growth is dependent on both the xylem and phloem streams however the contribution of vascular streams through verasion and ripening remains unclear (Rogiers et al 2001). Grape berries are very rich in potassium which like in other plants, plays a key role in the grapevine physiology. Depending on the developmental stage, potassium may play different roles during grape berry development. For instance, during early stages of berry growth, when the rate of cell division and expansion is high, potassium may play a significant role as an osmoregulator. After verasion, when the berries enlarge in size due to increase in sugars in the cell vacuole potassium 
plays an secondary role in the sugar accumulation. In grape berries, minerals, such as magnesium and calcium, together with negligible amounts of sodium and iron are also present. The concentration of calcium reaches its maximum during verasion, and afterwards either remains stable or decreases. At the vine level, high levels of calcium in the berry increases disease. resistance (Chardonnet and Doneche 1995), while defi ciencies in phosphorus, zinc, manganese and molybdenum result in a reduction of fruit set and a deficiency in potassium results in unevenly ripened berries (Mullins et al. 1996) Calcium plays an important role in the resistance against Botrytis cinerea infection. Magnesium, an important component of chlorophyll is present in grape berries at levels comparable to calcium. Nitrogen like in other organisms plays an important role in grape vine development. In grape berries nitrogen is either present as mineral compound such as ammonia, nitrate or nitrite or in organic form such as free amino acids, proteins, urea and nucleic acids.

An understanding of the patterns of mineral element accumulation into the berry components would not only aid in vine nutrition, harvest and grape processing decisions but also provide further information to viticulturists and enologists because of their impact on juice nutritional value. The aim of the present study was to determine the mineral composition of berry skin and juice of the grape genotypes at four developmental stages of berry ripening to elucidate their nutraceutical benefits.

\section{Material and Methods:-}

The grape genotypes, namely Punjab MACS Purple, Pusa Navrang, H-27, Carolina Black Rose, H-144, Merlot, Shiraz, Muscat hamburg, Perlette and Flame seedless were selected for the present study. Grape berries were collected from these genotypes planted at the Fruit Research Farm, Department of Fruit Science, PAU Ludhiana. The vines were grown under uniform orchard management practices. The berries were collected at four developmental stages viz; unripe, verasion, early ripe and ripe and were brought to the plant nutrition laboratory for elemental analysis. The data was recorded for two consecutive years (2015 and 2016). The selected berries were finger pressed to remove juice and pulp. Seeds and skin were separated, washed several times with distilled water, and moisture was absorbed on blotting paper.

\section{Estimation of Nutrients}

Potassium was determined following the Flame photometer method (AOAC 1990). For the determination of nitrogen, $5 \mathrm{ml}$ of juice and $5 \mathrm{~g}$ of grape skin was digested in $7-8 \mathrm{ml}$ concentrated $\mathrm{H}_{2} \mathrm{SO}_{4}$ along with digestion mixture in Kel Plus Nitrogen Estimation system(Pelican,Chennai).Calcium was determined with atomic absorption spectrophotometer(AANALYST 200,Perkin Elmer) method described by Bradfield and Spencer (1965).

\section{Statistical analysis:-}

All the experiments were done in triplicate. Significant differences between means were subjected to analysis of variance (ANOVA) followed by Tukey's test at the $\mathrm{P}<0.05$ level. Computations were done by SPSS for windows version 16.0.

\section{Results and Discussion:- \\ Skin metabolites}

The potassium, calcium and nitrogen were determined in the skin of ten grape genotypes at four different stages of berry development. The total potassium content $(\%)$ in the skin of grape berries at different stages of development is depicted in the table 1 . The analysis of variance exhibited that the potassium content increased significantly with berry ripening during both the years of investigation. During 2015, the mean total potassium content was maximum in $\mathrm{H}-27(2.800 \%)$ at ripened stage $(2.218 \%)$ which was significantly higher as compared to the other varieties and minimum in Punjab MACS Purple (0.812\%). During the year 2016, the mean total content of phenols was also maximum in $\mathrm{H}-27(2.600 \%)$ at ripened stage ( $1.196 \%)$. The interaction of the combined mean of data showed that potassium content was maximum in $\mathrm{H}-27$ (3.22\%) at ripened stage (fig. 1 )

The nutrients such as potassium are predominantly deposited in the pulp and skin of the berry. It has been reported by Rogiers et al 2006 that the potassium accumulation into the pulp and skin increased upto 90DAF with the pulp containing $59 \%$ of total berry potassium while the skin contained $32 \%$ of the potassium. Wall loosening is the primary event initiating cell expansion in grape berries (Cosgrove 1997). In grapes, the increase in berry softening and the decrease in skin elasticity (Huang and Huang 2001) lead to rapid berry expansion at verasion. This suggests that the cell walls in berry skin must loosen for berry expansion to begin. Loosening of cell wall material involves 
the acidification of the apoplast and the action of cell wall loosening enzymes (Hager et al 1971). Acidification occurs when protons $\left(\mathrm{H}^{+}\right)$are pumped out of the cytoplasm and into the apoplast by the membrane-bound ATPase Proton extrusion depends on the presence of $\mathrm{K}$ in the apoplast since the uptake of potassium ions $\left(\mathrm{K}^{+}\right)$balances the release of $\mathrm{H}^{+}$to keep the plasma membrane potential steady which may be possible reason for increase in potassium concentration with ripening as reported in the present investigation.

The total calcium in the grape berry skin also peaked with the ripening of grape berries and was maximum during ripened stage. During 2015, the maximum mean total calcium was observed in the Punjab MACS Purple $(0.497 \mathrm{mg} / \mathrm{l})$ at ripened stage $(0.515 \mathrm{mg} / \mathrm{l})$ and minimum in Pusa Navrang $(0.216 \mathrm{mg} / \mathrm{l})$ (Table 2). Same trend was followed during the second the year of investigation with the maximum total calcium in Punjab MACS Purple $(0.432 \mathrm{mg} / \mathrm{l})$ at ripened stage $(0.434 \mathrm{mg} / \mathrm{l})$ and minimum in Pusa Navrang.The interaction of combined mean of data (Fig 2 )showed that total calcium was maximum in Punjab MACS Purple(0.700mg/l). Calcium is one of the minerals thought to be an important factor governing the quality of fruit storage. The results of the present investigation are in agreement with Cabanne and Donecha (2003) who reported that in grape berries $\mathrm{Ca}^{+2}$ content increased in the pericarp and flesh until verasion and decreased afterwards which is consistent with the reduction of xylem flow after this stage. But in contrast, skin showed increased $\mathrm{Ca}^{+2}$ concentration throughout ripening that reached a plateau around maturity and accumulated in concentration slightly above those in flesh. Etcherbane (2009) while studying the influence of water status on mineral composition of berries (Vitis vinifera L.) observed that during ripening there was increase in $\mathrm{Ca}^{+2}$ in the skin of both irrigated and non-irrigated berries. $\mathrm{Ca}^{+2}$ transport to the skin cells during ripening could be explained by the apoplastic and symplastic migration into the berry or by partial function of xylem after verasion.

The analysis of variance show that the total nitrogen content of the grape berries significantly decreased with the maturity as the inorganic nitrogen is incorporated into the organic compounds of nitrogen such as proteins, amino acids, peptides, amides etc during maturation. During the first year of investigation, the highest total content of nitrogen was observed at green stage $(0.446 \mathrm{mg} / \mathrm{l})$ in Merlot $(0.336 \mathrm{mg} / \mathrm{l})$ which was at par with Punjab MACS Purple $(0.328 \mathrm{mg} / \mathrm{l})$ and minimum amount was found in Carolina Black Rose $(0.121 \mathrm{mg} / \mathrm{l})$ that was statistically at par with Flame Seedless $(0.113 \mathrm{mg} / \mathrm{l})$. During the second year of investigation, the maximum nitrogen content was recorded at green stage $(0.394 \mathrm{mg} / \mathrm{l})$ in H-27 $(0.522 \mathrm{mg} / \mathrm{l})$ statistically at par with Shiraz $(0.478 \mathrm{mg} / \mathrm{l})$ and minimum in Carolina Black Rose $(0.093 \mathrm{mg} / \mathrm{l})$ statistically at par with Muscat Hamburg $(0.211 \mathrm{mg} / \mathrm{l})$ and Perlette $(0.158 \mathrm{mg} / \mathrm{l})$ (table 3). The combined results of interaction (Fig3) indicated that maximum total nitrogen was observed at green stage in H-27(0.417 mg/l) being at par with Shiraz $(0.408 \mathrm{mg} / \mathrm{l})$. Nitrogen comes in a number of chemical forms and is an essential component of amino acids which are the building blocks for the more complex proteins that often act as hormones and enzymes in metabolic processes in the vine. During Phase 3 of berry development, 80\% of the nitrogen in berries is in the skins and seeds, while the juice contains barely $20 \%$ of the total berry nitrogen. Over the period of maturation, the ammonium concentration in berries decreases after verasion and the protein fraction increases, as ammonium is gradually incorporated into more complex compounds within the berry. Up to verasion, $\mathrm{N}$ concentration of the flesh is higher than that of the skin, but from the start of ripening skin $\mathrm{N}$ concentration exceeds the flesh $\mathrm{N}$ concentration. This seems to indicate that $\mathrm{N}$ is partitioned mainly to the skin during ripening.

\section{Juice Metabolites:}

The potassium, calcium and nitrogen were determined at four different stages of development in the juice of ten grape genotypes. The total potassium content (\%) in the juice of grape berries at different stages of development is depicted in the table 4 . The analysis of variance revealed that the potassium content increased significantly with the berry ripening during both the years of investigation. During the year 2015, the maximum potassium content was observed in Perlette (1.610\%) at ripened stage (1.090\%). and minimum in Carolina Black Rose (0.387\%). In the year 2016, the potassium content was also maximum at ripened $(0.966 \%)$ and minimum at green stage $(0.598 \%)$ and among different genotypes studied, the maximum potassium content was observed in Perlette (1.502\%) and minimum in Pusa Navrang $(0.388 \%)$. The interaction results showed that the potassium content was maximum at ripened stage in Perlette (1.728\%) which was significantly more as compared to other genotypes (fig4).

Grape berries are rich in potassium which is an essential macronutrient for grapevine and grape berry growth and development and is generally considered as the phloem mobile element and thus the high rates of accumulation after verasion is consistent with the flow through phloem into grape berries after verasion (Lang and Thorpe 1989; Greenspan 1996; Blouin and Cruege 2003). Depending on the developmental stage, potassium plays different roles during berry development. During the initial stages of rapid cell growth, potassium may play an important role as an 
osmoregulator. After verasion grape berries enlarge due to the increase in sugar content and thus during this phase potassium plays an important secondary role in accumulation of sugars.

The calcium content of the juice increased until verasion followed by a decrease during both the years of investigation. During the year 2015 , the calcium content peaked at verasion $(0.365 \mathrm{mg} / \mathrm{l})$ and then declined with maturation reaching its minimum value at ripened stage $(0.220 \mathrm{mg} / \mathrm{l})$. Among different genotypes, the maximum calcium content was observed in Punjab MACS Purple $(0.403 \mathrm{mg} / \mathrm{l})$ and minimum in Pusa Navrang $(0.130 \mathrm{mg} / \mathrm{l})$ (Table5). In 2016, the calcium content was maximum at verasion $(0.291 \mathrm{mg} / \mathrm{l})$ and minimum at ripened stage $(0.158 \mathrm{mg} / \mathrm{l})$ and among different genotypes studied, the maximum calcium content was observed in Punjab MACS Purple $(0.332 \mathrm{mg} / \mathrm{l})$ and minimum in Pusa Navrang $(0.095 \mathrm{mg} / \mathrm{l})$. The interaction of combined data showed that the calcium content was maximum at verasion stage in Punjab MACS Purple (0.579mg/l) (Fig 5).

The nitrogen content in the juice decreased with the maturation during the both years of investigation. During the year 2015 , the nitrogen content was maximum at green stage $(0.202 \%)$ and then decreased rapidly till the verasion stage $(0.078 \%)$ and after verasion showed a steady decline till maturity and reached its minimum at ripened stage $(0.042 \%)$ (table 6) .Among the different genotypes studied, the maximum nitrogen content was recorded in Perlette $(0.184 \%)$ and minimum in Flame Seedless $(0.044 \%)$. The grape juice nitrogen accumulation followed a similar trend during the second year of investigation with maximum during green stage $(0.052 \%)$ and minimum at ripened stage $(0.024 \%)$ which was statistically at par with unripe stage $(0.031 \%)$. Among the different genotypes maximum nitrogen content in the juice was observed in Perlette (0.129\%) and minimum in Flame Seedless $(0.030 \%)$ which was statistically nonsignificant when compared with Punjab MACS Purple $(0.043 \%)$ and $\mathrm{H}-27(0.036 \%)$. The interaction results indicate that maximum nitrogen content was at green stage in Perlette $(0.310 \%)$ which was statistically high compared to the other genotypes studied. (Fig 6). The total nitrogen concentration of the fruit increases during the maturation period. Nitrogenous compounds are important because they serve as nutrients for yeast and lactic acid bacteria in wine grapes during the fermentation process (Conde et al 2007).

\section{Conclusion:-}

The total potassium, calcium and nitrogen content in the grape genotypes showed significant differences in berry skin, juice and evaluation years. In this study, the maximum calcium was recorded in Punjab MACS Purple in skin $(0.745 \mathrm{mg} / \mathrm{l})$ and juice at ripened stage. The maximum potassium was also at ripened stage in the skin of H-27( $3.370 \%$ ) and juice of Perlette( $1.830 \%$ ). Thus, the grape berries which are comsumed both as fresh fruit as well as processed such as wine are the rich sources of natural mineral nutrients with numerous health benefits. Therefore, the present study emphasis the value of use of these natural resources and promote their cultivation on the basis of identified neutraceutical benefits.

Total potassium (\%) in the skin of grape genotypes at different stages of berry development

\begin{tabular}{|c|c|c|c|c|c|c|c|c|c|c|}
\hline \multirow[b]{2}{*}{$\begin{array}{l}\text { Stages } \\
\text { Genotype } \\
\text { s }\end{array}$} & \multicolumn{5}{|c|}{2015} & \multicolumn{5}{|c|}{2016} \\
\hline & $\begin{array}{c}\text { Green } \\
\text { stage }\end{array}$ & $\begin{array}{l}\text { Verasio } \\
\text { n stage }\end{array}$ & $\begin{array}{c}\text { Early } \\
\text { ripe }\end{array}$ & $\begin{array}{l}\text { Ripene } \\
\text { d stage }\end{array}$ & Mean & $\begin{array}{c}\text { Green } \\
\text { stage }\end{array}$ & $\begin{array}{l}\text { Verasio } \\
\text { n stage }\end{array}$ & $\begin{array}{c}\text { Early } \\
\text { ripe }\end{array}$ & $\begin{array}{l}\text { Ripene } \\
\text { d stage }\end{array}$ & Mean \\
\hline $\begin{array}{l}\text { Punjab } \\
\text { MACS } \\
\text { Purple }\end{array}$ & $0.723^{\text {Id }}$ & $0.783^{\mathrm{Ic}}$ & $0.843^{\text {lb }}$ & $0.900^{\mathrm{Ia}}$ & $0.812^{1}$ & $0.620^{\text {id }}$ & $0.680^{\text {ic }}$ & $0.757^{\mathrm{ib}}$ & $0.853^{\text {ia }}$ & $0.727^{1}$ \\
\hline $\begin{array}{l}\text { Flame } \\
\text { Seedless }\end{array}$ & $1.367^{\mathrm{Ed}}$ & $1.700^{\mathrm{Ec}}$ & $1.900^{\mathrm{Eb}}$ & $2.333^{\mathrm{Ea}}$ & $1.825^{\mathrm{E}}$ & $1.323^{E}$ & $1.530^{\mathrm{Ec}}$ & $\underset{b}{1.740^{\mathrm{E}}}$ & $1.940^{\mathrm{Ea}}$ & $\underset{E}{1.633}$ \\
\hline Merlot & $2.247^{\mathrm{Cd}}$ & $2.467^{\mathrm{Cc}}$ & $2.667^{\mathrm{Cb}}$ & $2.907^{\mathrm{Ca}}$ & $2.572^{C}$ & $\underset{\mathrm{d}}{2.000^{C}}$ & $2.333^{\mathrm{Cc}}$ & $\underset{\mathrm{b}}{2.540^{\mathrm{C}}}$ & $2.730^{\mathrm{Ca}}$ & $\underset{\mathrm{C}}{2.401}$ \\
\hline $\begin{array}{l}\text { Muscat } \\
\text { Hamburg }\end{array}$ & $2.320^{\mathrm{Bd}}$ & $2.480^{\mathrm{Bc}}$ & $2.817^{\mathrm{Bb}}$ & $3.100^{\mathrm{Ba}}$ & $2.679^{\mathrm{B}}$ & $\underset{\mathrm{d}}{2.137^{\mathrm{B}}}$ & $2.320^{\mathrm{BC}}$ & $\underset{\mathrm{a}}{2.600^{\mathrm{B}}}$ & $2.863^{\mathrm{Ba}}$ & 2.480 \\
\hline $\begin{array}{l}\text { Pusa } \\
\text { Navrang }\end{array}$ & $0.523^{\mathrm{HI}}$ & $0.757^{\mathrm{HIC}}$ & $0.930^{\mathrm{HI}}$ & $1.223^{\mathrm{HIa}}$ & $\underset{\mathrm{I}}{0.858^{\mathrm{H}}}$ & $0.343^{\text {Jd }}$ & $0.520^{\mathrm{Jc}}$ & $0.757^{\mathrm{bb}}$ & $0.957^{\mathrm{Ja}}$ & $0.644^{\mathrm{J}}$ \\
\hline $\begin{array}{l}\text { Carolina } \\
\text { Black }\end{array}$ & $0.720^{\mathrm{Hd}}$ & $0.837^{\mathrm{Hc}}$ & $0.923^{\mathrm{Hb}}$ & $1.067^{\mathrm{Ha}}$ & $0.887^{\mathrm{H}}$ & $0.667^{\mathrm{H}}$ & $0.750^{\mathrm{Hc}}$ & $\underset{\mathrm{b}}{0.830^{\mathrm{H}}}$ & $0.950^{\mathrm{Ha}}$ & $\begin{array}{c}0.799 \\
\mathrm{H}\end{array}$ \\
\hline
\end{tabular}




\begin{tabular}{|c|c|c|c|c|c|c|c|c|c|c|}
\hline \multicolumn{11}{|l|}{ Rose } \\
\hline Shiraz & $0.520^{\mathrm{Gd}}$ & $0.823^{\mathrm{Gc}}$ & $1.233^{\mathrm{Gb}}$ & $1.553^{\mathrm{Ga}}$ & $1.032^{\mathrm{G}}$ & $0.467^{G}$ & $0.533^{\mathrm{Gc}}$ & $0.950^{G}$ & $1.370^{\mathrm{Ga}}$ & 0.830 \\
\hline H-27 & $2.067^{\mathrm{Ad}}$ & $2.757^{\mathrm{Ac}}$ & $3.007^{\mathrm{Ab}}$ & $3.370^{\mathrm{Aa}}$ & $2.800^{\mathrm{A}}$ & $1.960^{A}$ & $2.537^{\mathrm{Ac}}$ & $\underset{b}{2.833^{A}}$ & $3.070^{\mathrm{Aa}}$ & $\underset{\mathrm{A}}{2.600}$ \\
\hline H-144 & $1.417^{\mathrm{Fd}}$ & $1.520^{\mathrm{Fc}}$ & $1.730^{\mathrm{Fb}}$ & $2.077^{\mathrm{Fa}}$ & $1.686^{\mathrm{F}}$ & $1.360^{F}$ & $1.420^{\mathrm{Fc}}$ & $\underset{b}{1.653^{F}}$ & $1.850^{\mathrm{Fa}}$ & 1.571 \\
\hline Perlette & $1.347^{\mathrm{Dd}}$ & $1.750^{\mathrm{Dc}}$ & $2.037^{\mathrm{Db}}$ & $2.750^{\mathrm{Da}}$ & $1.971^{\mathrm{D}}$ & $1.080^{D}$ & $1.537^{\mathrm{Dc}}$ & ${ }_{\mathrm{b}}^{1.830^{\mathrm{D}}}$ & $2.440^{\mathrm{Da}}$ & $\begin{array}{c}1.722 \\
\text { D }\end{array}$ \\
\hline Mean & $1.325^{\mathrm{d}}$ & $1.587^{\mathrm{c}}$ & $1.809^{b}$ & $2.218^{\mathrm{a}}$ & & $1.196^{\mathrm{d}}$ & $1.416^{\mathrm{c}}$ & $1.649^{\mathrm{b}}$ & $1.902^{\mathrm{a}}$ & \\
\hline
\end{tabular}

Values with different superscripts are significantly different at $\mathrm{p}<0.05$ by tukey's test for interaction between genotypes and stages

Capital letters denotes significance level of genotypes.

Small letters denotes significance level of stages

Calcium (mg/l) in the Peel of grape genotypes at different stages of berry development

\begin{tabular}{|c|c|c|c|c|c|c|c|c|c|c|}
\hline \multirow{2}{*}{$\begin{array}{l}\text { Stages } \\
\text { Genotype } \\
5\end{array}$} & \multicolumn{5}{|c|}{2015} & \multicolumn{5}{|c|}{2016} \\
\hline & $\begin{array}{c}\text { Green } \\
\text { stage }\end{array}$ & $\begin{array}{l}\text { Verasio } \\
\text { n stage }\end{array}$ & $\begin{array}{c}\text { Early } \\
\text { ripe }\end{array}$ & $\begin{array}{l}\text { Ripene } \\
\text { d stage }\end{array}$ & Mean & $\begin{array}{c}\text { Green } \\
\text { stage }\end{array}$ & $\begin{array}{l}\text { Verasio } \\
\text { n stage }\end{array}$ & $\begin{array}{l}\text { Early } \\
\text { ripe }\end{array}$ & $\begin{array}{l}\text { Ripene } \\
\text { d stage }\end{array}$ & Mean \\
\hline $\begin{array}{l}\text { Punjab } \\
\text { MACS } \\
\text { Purple }\end{array}$ & $0.276^{\mathrm{A}}$ & $0.303^{\mathrm{Ac}}$ & $\underset{b}{0.663^{A}}$ & $0.745^{\mathrm{Aa}}$ & $\underset{\mathrm{A}}{0.497}$ & $0.255^{A}$ & $0.285^{\mathrm{Ac}}$ & $0.534^{\mathrm{A}}$ & $0.655^{\mathrm{Aa}}$ & 0.432 \\
\hline $\begin{array}{l}\text { Flame } \\
\text { Seedless }\end{array}$ & $\underset{\mathrm{d}}{0.279^{\mathrm{H}}}$ & $0.274^{\mathrm{Hc}}$ & $\underset{b}{0.276^{\mathrm{H}}}$ & $0.382^{\mathrm{Ha}}$ & $\begin{array}{c}0.303 \\
\mathrm{H}\end{array}$ & $0.237^{\mathrm{G}}$ & $0.252^{\mathrm{Gc}}$ & $\underset{b}{0.253^{G}}$ & $0.275^{\mathrm{Ga}}$ & $\underset{\mathrm{G}}{0.254}$ \\
\hline Merlot & $0.253^{\text {Id }}$ & $0.273 \mathrm{I}^{\mathrm{c}}$ & $0.104^{\mathrm{Ib}}$ & $0.275^{\text {la }}$ & $0.226^{1}$ & $0.204^{C}$ & $0.235^{\mathrm{Cc}}$ & $\underset{b}{0.987^{C}}$ & $0.204^{\mathrm{Ca}}$ & $\underset{\mathrm{C}}{0.407}$ \\
\hline $\begin{array}{l}\text { Muscat } \\
\text { Hamburg }\end{array}$ & $0.335^{G}$ & $0.337^{\mathrm{Gc}}$ & $\underset{b}{0.262^{G}}$ & $0.364^{\mathrm{Ga}}$ & $\underset{\mathrm{G}}{0.324}$ & $0.286^{G}$ & $0.242^{\mathrm{Gc}}$ & $\underset{\mathrm{b}}{0.207^{\mathrm{G}}}$ & $0.287^{\mathrm{Ga}}$ & 0.256 \\
\hline $\begin{array}{l}\text { Pusa } \\
\text { Navrang }\end{array}$ & $0.227^{\text {Jd }}$ & $0.250^{\mathrm{Jc}}$ & $0.134^{\mathrm{Jb}}$ & $0.254^{\mathrm{Ja}}$ & $0.216^{\top}$ & $0.125^{\mathrm{H}}$ & $0.188^{\mathrm{Hc}}$ & $\underset{b}{0.106^{\mathrm{H}}}$ & $0.177^{\text {Ha }}$ & $\underset{\mathrm{H}}{0.149}$ \\
\hline $\begin{array}{l}\text { Carolina } \\
\text { Black } \\
\text { Rose }\end{array}$ & $0.244^{E}$ & $0.253^{\mathrm{Ec}}$ & $\underset{b}{0.529^{E}}$ & $0.594^{\mathrm{Ea}}$ & $0.405^{\mathrm{E}}$ & $0.137^{E}$ & $0.207^{\mathrm{Ec}}$ & $\underset{b}{0.357^{E}}$ & $0.486^{\mathrm{Ea}}$ & $0.297^{\mathrm{E}}$ \\
\hline Shiraz & $0.462^{C}$ & $0.482^{\mathrm{Cc}}$ & $\underset{b}{0.264^{C}}$ & $0.672^{\mathrm{Ca}}$ & $\begin{array}{c}0.470 \\
\mathrm{C}\end{array}$ & $0.415^{C}$ & $0.424^{\mathrm{Cc}}$ & $\underset{b}{0.244^{C}}$ & $0.545^{\mathrm{Ca}}$ & $\begin{array}{c}0.407 \\
\mathrm{C}\end{array}$ \\
\hline H-27 & $0.2 \underset{d}{286^{B}}$ & $0.453^{\mathrm{Bc}}$ & $\underset{b}{0.513^{B}}$ & $0.705^{\mathrm{Ba}}$ & $\underset{B}{0.489}$ & $0.167^{B}$ & $0.377^{\mathrm{Bc}}$ & $0.484^{\mathrm{B}}$ & $0.685^{\mathrm{Ba}}$ & 0.428 \\
\hline H-144 & $0.264^{D}$ & $0.264^{\mathrm{Dc}}$ & $0.484^{D}$ & $0.636^{\mathrm{Da}}$ & $\underset{\mathrm{D}}{0.412}$ & $0.205^{D}$ & $0.205^{\mathrm{Dc}}$ & $0.377^{\mathrm{D}}$ & $0.545^{\mathrm{Da}}$ & $\begin{array}{c}0.333 \\
\mathrm{D}\end{array}$ \\
\hline Perlette & $0.273^{\mathrm{Fd}}$ & $0.275^{\mathrm{Fc}}$ & $0.325^{\mathrm{Fb}}$ & $0.523^{\mathrm{Fa}}$ & $0.349^{\mathrm{F}}$ & $0.175^{\mathrm{Fd}}$ & $0.187^{\mathrm{Fc}}$ & $0.284^{\mathrm{Fb}}$ & $0.484^{\mathrm{Fa}}$ & $0.283^{\mathrm{F}}$ \\
\hline Mean & $0.290^{\mathrm{d}}$ & $0.316^{\mathrm{c}}$ & $0.355^{\mathrm{b}}$ & $0.515^{\mathrm{a}}$ & 0.369 & $0.221^{\mathrm{d}}$ & $0.260^{c}$ & $0.383^{b}$ & $0.434^{\mathrm{a}}$ & 0.324 \\
\hline
\end{tabular}

Values with different superscripts are significantly different at $p<0.05$ by tukey's test for interaction between genotypes and stages

Capital letters denotes significance level of genotypes.

Small letters denotes significance level of stages

Total Nitrogen in the peel of grape genotypes at different stages of berry development

\begin{tabular}{|c|c|c|c|c|c|c|c|c|c|c|}
\hline Stages & \multicolumn{9}{|c|}{2015} \\
\cline { 2 - 7 } & $\begin{array}{c}\text { Green } \\
\text { stage }\end{array}$ & $\begin{array}{c}\text { Verasio } \\
\text { n stage }\end{array}$ & $\begin{array}{c}\text { Early } \\
\text { ripe }\end{array}$ & $\begin{array}{c}\text { Ripene } \\
\text { d stage }\end{array}$ & Mean & $\begin{array}{c}\text { Green } \\
\text { stage }\end{array}$ & $\begin{array}{c}\text { Verasio } \\
\text { n stage }\end{array}$ & $\begin{array}{c}\text { Early } \\
\text { ripe }\end{array}$ & $\begin{array}{c}\text { Ripene } \\
\text { d stage }\end{array}$ & Mean \\
\hline
\end{tabular}




\begin{tabular}{|c|c|c|c|c|c|c|c|c|c|c|}
\hline $\mathbf{s}$ & & & & & & & & & & \\
\hline $\begin{array}{l}\text { Punjab } \\
\text { MACS } \\
\text { Purple }\end{array}$ & $0.617^{a \mathrm{aB}}$ & $0.323^{\mathrm{ABb}}$ & $0.217^{\mathrm{A}}$ & $0.153^{A B}$ & $\underset{B}{0.328^{A}}$ & $\underset{\mathrm{Da}}{0.557^{\mathrm{C}}}$ & $0.260^{\mathrm{CDb}}$ & $0.163^{C D}$ & $0.113^{C D}$ & $\underset{D}{0.273^{C}}$ \\
\hline $\begin{array}{l}\text { Flame } \\
\text { Seedless }\end{array}$ & $0.233^{\mathrm{Fa}}$ & $0.113^{\mathrm{Fb}}$ & $0.067^{\mathrm{Fc}}$ & $0.037^{\mathrm{Fd}}$ & $0.113^{\mathrm{F}}$ & $0.463^{B C}$ & $0.970^{\mathrm{BCb}}$ & $0.030^{B C}$ & $0.017^{\mathrm{BC}}$ & $\begin{array}{c}0.370^{B} \\
{ }^{B}\end{array}$ \\
\hline Merlot & $0.547^{\mathrm{Aa}}$ & $0.323^{\mathrm{Ab}}$ & $0.263^{\mathrm{Ac}}$ & $0.210^{\mathrm{Ad}}$ & $0.336^{\mathrm{A}}$ & $\begin{array}{c}0.470^{\mathrm{C}} \\
\mathrm{Da}\end{array}$ & $0.310^{\mathrm{CDb}}$ & $0.217^{\mathrm{CD}}$ & $0.127^{1}{ }^{C D}$ & $\underset{D}{0.281^{C}}$ \\
\hline $\begin{array}{l}\text { Muscat } \\
\text { Hambur } \\
\text { g }\end{array}$ & $\underset{\mathrm{Da}}{0.533^{\mathrm{C}}}$ & $0.217^{\mathrm{CDb}}$ & $0.137^{\mathrm{C}}$ & $0.123^{C D}$ & $\underset{D}{0.253^{C}}$ & $\underbrace{0.440^{\mathrm{DE}}}_{\mathrm{a}}$ & $0.173^{\text {DEb }}$ & $0.113^{\mathrm{DE}}$ & $0.117^{\mathrm{bE}}$ & $0.211^{D}$ \\
\hline $\begin{array}{l}\text { Pusa } \\
\text { Navrang }\end{array}$ & $0.327^{\mathrm{Ca}}$ & $0.247^{\mathrm{cb}}$ & $0.260^{\mathrm{Cc}}$ & $0.230^{\mathrm{Cd}}$ & $0.266^{\mathrm{C}}$ & $0.310^{\mathrm{Da}}$ & $0.223^{\mathrm{Db}}$ & $0.170^{\mathrm{Db}}$ & $0.203^{\mathrm{Db}}$ & $0.227^{\mathrm{D}}$ \\
\hline $\begin{array}{l}\text { Carolina } \\
\text { Black } \\
\text { Rose }\end{array}$ & $0.273^{\mathrm{Fa}}$ & $0.117^{\mathrm{Fb}}$ & $0.053^{\mathrm{Fc}}$ & $0.040^{\mathrm{Fd}}$ & $0.121^{\mathrm{F}}$ & $0.217^{\mathrm{Ea}}$ & $0.113^{\mathrm{Eb}}$ & $0.030^{\mathrm{Eb}}$ & $0.013^{\mathrm{Eb}}$ & $0.093^{\mathrm{E}}$ \\
\hline Shiraz & $0.457^{\mathrm{Ea}}$ & $0.210^{\mathrm{Eb}}$ & $0.107^{\mathrm{Ec}}$ & $0.127^{\mathrm{Ed}}$ & $0.225^{\mathrm{E}}$ & $0.360^{\mathrm{A}}$ & $0.203^{\mathrm{ABb}}$ & $0.957^{\mathrm{AB}}$ & $0.393^{\mathrm{AB}}$ & $0.478^{\mathrm{A}}$ \\
\hline H-27 & $0.503^{\mathrm{Da}}$ & $0.220^{\mathrm{Db}}$ & $0.143^{\mathrm{Dc}}$ & $0.120^{\mathrm{Dd}}$ & $0.247^{\mathrm{D}}$ & $0.330^{\mathrm{Aa}}$ & $0.127^{\mathrm{Ab}}$ & $0.780^{\mathrm{Ab}}$ & $0.853^{\mathrm{Ab}}$ & $0.522^{\mathrm{A}}$ \\
\hline H-144 & $0.530^{\mathrm{Ba}}$ & $0.320^{\mathrm{Bb}}$ & $0.220^{\mathrm{BC}}$ & $0.200^{\mathrm{Bd}}$ & $0.318^{\mathrm{B}}$ & $\underset{\mathrm{Da}}{0.450^{\mathrm{C}}}$ & $0.273^{\mathrm{CDb}}$ & $0.160^{C D}$ & $0.167^{\mathrm{CD}}$ & ${ }_{D}^{0.262^{C}}$ \\
\hline Perlette & $0.437^{\text {Ea }}$ & $0.170^{\mathrm{Eb}}$ & $0.110^{\mathrm{Ec}}$ & $0.130^{\mathrm{Ed}}$ & $0.212^{\mathrm{E}}$ & $\begin{array}{c}0.343^{\mathrm{DE}} \\
\mathrm{a}\end{array}$ & $0.170^{\text {DEb }}$ & $0.073^{\mathrm{bE}}$ & $0.107^{\mathrm{bE}}$ & $0.158^{D}$ \\
\hline Mean & $0.446^{\mathrm{a}}$ & $0.226^{\mathrm{b}}$ & $0.158^{\mathrm{c}}$ & $0.137^{\mathrm{d}}$ & 0.241 & $0.394^{\mathrm{a}}$ & $0.276^{b}$ & $0.269^{b}$ & $0.211^{\mathrm{b}}$ & 0.287 \\
\hline
\end{tabular}

Values with different superscripts are significantly different at $p<0.05$ by tukey's test for interaction between genotypes and stages

Capital letters denotes significance level of genotypes.

Small letters denotes significance level of stages

Potassium (\%) in the juice of grape genotypes at different stages of berry development

\begin{tabular}{|c|c|c|c|c|c|c|c|c|c|c|}
\hline \multirow[b]{2}{*}{$\begin{array}{l}\text { Stages } \\
\text { Genotype } \\
\text { s }\end{array}$} & \multicolumn{5}{|c|}{2015} & \multicolumn{5}{|c|}{2016} \\
\hline & $\begin{array}{l}\text { Green } \\
\text { stage }\end{array}$ & $\begin{array}{l}\text { Verasio } \\
\text { n stage }\end{array}$ & $\begin{array}{c}\text { Early } \\
\text { ripe }\end{array}$ & $\begin{array}{l}\text { Ripene } \\
\text { d stage }\end{array}$ & Mean & $\begin{array}{c}\text { Green } \\
\text { stage }\end{array}$ & $\begin{array}{l}\text { Verasio } \\
\text { n stage }\end{array}$ & $\begin{array}{c}\text { Early } \\
\text { ripe }\end{array}$ & $\begin{array}{l}\text { Ripene } \\
\text { d stage }\end{array}$ & Mean \\
\hline $\begin{array}{l}\text { Punjab } \\
\text { MACS } \\
\text { Purple }\end{array}$ & $0.330^{G}$ & $0.537^{\mathrm{Gc}}$ & $0.717^{\mathrm{G}}$ & $0.820^{\mathrm{Ga}}$ & $\underset{\mathrm{G}}{0.601}$ & $0.270^{H}$ & $0.430^{\mathrm{Hc}}$ & $0.633^{\mathrm{H}}$ & $0.730^{\mathrm{Ha}}$ & $\underset{\mathrm{H}}{0.516}$ \\
\hline $\begin{array}{l}\text { Flame } \\
\text { Seedless }\end{array}$ & $0.430^{\text {hd }}$ & $0.717^{\mathrm{Hc}}$ & $\underset{\mathrm{b}}{0.923^{\mathrm{H}}}$ & $0.120^{\text {На }}$ & $\underset{\mathrm{H}}{0.547}$ & $0.377^{\mathrm{Ed}}$ & $0.570^{\mathrm{Ec}}$ & $0.847^{\mathrm{Eb}}$ & $0.933^{\mathrm{Ea}}$ & $0.682^{\mathrm{E}}$ \\
\hline Merlot & $0.703^{\mathrm{dd}}$ & $0.113^{\mathrm{dc}}$ & $1.210^{\mathrm{db}}$ & $1.413^{\mathrm{da}}$ & $\underset{\mathrm{D}}{0.860}$ & $\underset{d}{0.517^{C}}$ & $0.723^{\mathrm{Cc}}$ & $\underset{\mathrm{b}}{0.903^{\mathrm{C}}}$ & $1.077^{\mathrm{Ca}}$ & $\underset{\mathrm{C}}{0.805}$ \\
\hline $\begin{array}{l}\text { Muscat } \\
\text { Hamburg }\end{array}$ & $0.420^{\mathrm{fd}}$ & $0.647^{\mathrm{fc}}$ & $0.807^{\mathrm{tb}}$ & $1.031^{\mathrm{fa}}$ & $0.722^{\mathrm{F}}$ & $0.360^{\mathrm{Fd}}$ & $0.597^{\mathrm{Fc}}$ & $0.710^{\mathrm{Fb}}$ & $0.920^{\mathrm{Fa}}$ & $0.647^{\mathrm{F}}$ \\
\hline $\begin{array}{l}\text { Pusa } \\
\text { Navrang } \\
\end{array}$ & $\frac{0.223^{G}}{d}$ & $0.507^{\mathrm{Gc}}$ & $\begin{array}{c}0.713^{\mathrm{G}} \\
\mathrm{b}\end{array}$ & $0.910^{\mathrm{Ga}}$ & $\begin{array}{c}0.588 \\
\mathrm{G}\end{array}$ & $0.143^{\text {Jd }}$ & $0.220^{\mathrm{Jc}}$ & $0.413^{\mathrm{Jb}}$ & $0.773^{\mathrm{Ja}}$ & $0.388^{\mathrm{J}}$ \\
\hline $\begin{array}{l}\text { Carolina } \\
\text { Black } \\
\text { Rose }\end{array}$ & $0.120^{\text {Id }}$ & $0.317^{\mathrm{Ic}}$ & $0.510^{\mathrm{Ib}}$ & $0.600^{\mathrm{Ia}}$ & $0.387^{1}$ & $0.827^{\text {Id }}$ & $0.117^{\mathrm{Ic}}$ & $0.300^{\mathrm{lb}}$ & $0.463^{\mathrm{Ia}}$ & $0.427^{1}$ \\
\hline Shiraz & $0.307^{\mathrm{Ed}}$ & $0.517^{\mathrm{Ec}}$ & $0.907^{\mathrm{Eb}}$ & $1.310^{\mathrm{Ea}}$ & $0.760^{\mathrm{E}}$ & $0.227^{G}$ & $0.457^{\mathrm{Gc}}$ & $\underset{b}{0.700^{G}}$ & $0.873^{\mathrm{Ga}}$ & $\underset{G}{0.564}$ \\
\hline H-27 & $1.420^{B}$ & $1.500^{\mathrm{BC}}$ & $\underset{b}{1.617^{B}}$ & $1.707^{\mathrm{Ba}}$ & ${ }_{B}^{1.561}$ & $1.283^{B}$ & $0.870^{\mathrm{Bc}}$ & $1.523^{B}$ & $1.623^{\mathrm{Ba}}$ & ${ }_{\mathrm{B}}^{1.325}$ \\
\hline
\end{tabular}




\begin{tabular}{|l|c|c|c|c|c|c|c|c|c|c|}
\hline H-144 & $\begin{array}{c}0.717^{\mathrm{C}} \\
\mathrm{d}\end{array}$ & $0.900^{\mathrm{Cc}}$ & $\begin{array}{c}1.067^{\mathrm{C}} \\
\mathrm{b}\end{array}$ & $1.200^{\mathrm{Ca}}$ & $\begin{array}{c}0.971 \\
\mathrm{C}\end{array}$ & $\begin{array}{c}0.600^{\mathrm{D}} \\
\mathrm{d}\end{array}$ & $0.720^{\mathrm{Dc}}$ & $\begin{array}{c}0.807^{\mathrm{D}} \\
\mathrm{b}\end{array}$ & $0.917^{\mathrm{Da}}$ & $\begin{array}{c}0.761 \\
\mathrm{D}\end{array}$ \\
\hline Perlette & $\begin{array}{c}1.423^{\mathrm{A}} \\
\mathrm{d}\end{array}$ & $1.500^{\mathrm{Ac}}$ & $\begin{array}{c}1.713^{\mathrm{A}} \\
\mathrm{b}\end{array}$ & $1.803^{\mathrm{Aa}}$ & $\begin{array}{c}1.610 \\
\mathrm{~A}\end{array}$ & $\begin{array}{c}1.380^{\mathrm{A}} \\
{ }_{\mathrm{d}}\end{array}$ & $1.467^{\mathrm{Ac}}$ & $\begin{array}{c}1.507^{\mathrm{A}} \\
\mathrm{b}\end{array}$ & $1.653^{\mathrm{Aa}}$ & $\begin{array}{c}1.502 \\
\mathrm{~A}\end{array}$ \\
\hline Mean & $0.609^{\mathrm{d}}$ & $0.725^{\mathrm{C}}$ & $1.018^{\mathrm{b}}$ & $1.090^{\mathrm{a}}$ & & $0.598^{\mathrm{d}}$ & $0.617^{\mathrm{C}}$ & $0.834^{\mathrm{b}}$ & $0.966^{\mathrm{a}}$ & \\
\hline
\end{tabular}

Values with different superscripts are significantly different at $p<0.05$ by tukey's test for interaction between genotypes and stages

Capital letters denotes significance level of genotypes.

Small letters denotes significance level of stages

Calcium (mg/l) in the juice of grape genotypes at different stages of berry development

\begin{tabular}{|c|c|c|c|c|c|c|c|c|c|c|}
\hline \multirow[b]{2}{*}{\begin{tabular}{|l|} 
Stages \\
Genotype \\
s
\end{tabular}} & \multicolumn{5}{|c|}{2015} & \multicolumn{5}{|c|}{2016} \\
\hline & $\begin{array}{c}\text { Green } \\
\text { stage }\end{array}$ & $\begin{array}{l}\text { Verasio } \\
\text { n stage }\end{array}$ & $\begin{array}{c}\text { Early } \\
\text { ripe }\end{array}$ & $\begin{array}{l}\text { Ripene } \\
\text { d stage }\end{array}$ & Mean & $\begin{array}{l}\text { Green } \\
\text { stage }\end{array}$ & $\begin{array}{l}\text { Verasio } \\
\text { n stage }\end{array}$ & $\begin{array}{c}\text { Early } \\
\text { ripe }\end{array}$ & $\begin{array}{l}\text { Ripene } \\
\text { d stage }\end{array}$ & Mean \\
\hline $\begin{array}{l}\text { Punjab } \\
\text { MACS } \\
\text { Purple }\end{array}$ & $0.326^{A}$ & $0.603^{\mathrm{Aa}}$ & $0.332^{\mathrm{A}}$ & $0.350^{\mathrm{Ad}}$ & 0.403 & $\underset{\mathrm{c}}{0.243^{\mathrm{A}}}$ & $0.555^{\mathrm{Aa}}$ & $\underset{b}{0.275^{\mathrm{A}}}$ & $0.257^{\mathrm{d}}$ & $\underset{\mathrm{A}}{0.332}$ \\
\hline $\begin{array}{l}\text { Flame } \\
\text { Seedless }\end{array}$ & $\underset{c}{0.085^{\mathrm{H}}}$ & $0.266^{\mathrm{Ha}}$ & $0.104^{\mathrm{H}}$ & $0.104^{\mathrm{Hd}}$ & $\begin{array}{c}0.140 \\
\mathrm{H}\end{array}$ & $\underset{c}{0.075^{\mathrm{G}}}$ & $0.202^{\mathrm{Ga}}$ & $\underset{\mathrm{b}}{0.098^{\mathrm{G}}}$ & $0.091^{\text {gd }}$ & $\underset{\mathrm{G}}{0.116}$ \\
\hline Merlot & $0.075^{\mathrm{G}}$ & $0.182^{\mathrm{Ga}}$ & $0.174^{\mathrm{G}}$ & $0.173^{\text {Gd }}$ & 0.151 & $0.035^{\mathrm{G}}$ & $0.163^{\mathrm{Ga}}$ & $0.144^{\mathrm{G}}$ & $0.123^{\text {Gd }}$ & $\underset{G}{0.116}$ \\
\hline $\begin{array}{l}\text { Muscat } \\
\text { Hamburg }\end{array}$ & $0.215^{\mathrm{Ec}}$ & $0.293^{\mathrm{Ea}}$ & $0.284^{\mathrm{Eb}}$ & $0.282^{\mathrm{Ed}}$ & $0.269^{\mathrm{E}}$ & $0.205^{\mathrm{Ec}}$ & $0.254^{\mathrm{Ea}}$ & $0.228^{\mathrm{Eb}}$ & $0.181^{\text {Ed }}$ & $0.217^{\mathrm{E}}$ \\
\hline $\begin{array}{l}\text { Pusa } \\
\text { Navrang }\end{array}$ & $0.107^{\text {Ic }}$ & $0.216^{\mathrm{Ia}}$ & $0.104^{\mathrm{Ib}}$ & $0.096^{\text {Id }}$ & $0.130^{\mathrm{I}}$ & $0.103^{\mathrm{Ic}}$ & $0.121^{\mathrm{Ia}}$ & $0.087^{\mathrm{lb}}$ & $0.068^{\text {Id }}$ & $0.095^{\mathrm{I}}$ \\
\hline $\begin{array}{l}\text { Carolina } \\
\text { Black } \\
\text { Rose }\end{array}$ & $0.225^{\mathrm{Ec}}$ & $0.339^{\mathrm{Ea}}$ & $0.256^{\mathrm{Eb}}$ & $0.254^{\mathrm{Ed}}$ & $0.269^{\mathrm{E}}$ & $0.175^{\mathrm{Fc}}$ & $0.215^{\mathrm{Fa}}$ & $0.237^{\mathrm{Fb}}$ & $0.204^{\mathrm{Fd}}$ & $0.208^{\mathrm{F}}$ \\
\hline Shiraz & $0.317^{\mathrm{C}}$ & $0.442^{\mathrm{Ca}}$ & $0.355^{\mathrm{C}}$ & $0.316^{\mathrm{Cd}}$ & $\underset{\mathrm{C}}{0.358}$ & $\underset{c}{0.264^{C}}$ & $0.305^{\mathrm{Ca}}$ & $\underset{b}{0.352^{C}}$ & $0.265^{\mathrm{Cd}}$ & $\underset{\mathrm{C}}{0.297}$ \\
\hline H-27 & $\underset{c}{0.404^{B}}$ & $0.504^{\mathrm{Ba}}$ & $\underset{\mathrm{b}}{0.372^{\mathrm{B}}}$ & $0.254^{\mathrm{Bd}}$ & $\begin{array}{c}0.384 \\
B\end{array}$ & $0.375^{B}$ & $0.448^{\mathrm{Ba}}$ & $\underset{\mathrm{b}}{0.252^{\mathrm{B}}}$ & $0.188^{\mathrm{Bd}}$ & $\underset{B}{0.316}$ \\
\hline H-144 & $0.431^{D}$ & $0.525^{\mathrm{Da}}$ & $\underset{\mathrm{b}}{0.206^{\mathrm{D}}}$ & $0.204^{\mathrm{Dd}}$ & $\underset{\mathrm{D}}{0.342}$ & $0.327^{\mathrm{D}}$ & $0.463^{\mathrm{Da}}$ & $0.187^{D}$ & $0.104^{\mathrm{Dd}}$ & $\underset{\mathrm{D}}{0.270}$ \\
\hline Perlette & $0.088^{\mathrm{Fc}}$ & $0.284^{\mathrm{Fa}}$ & $0.172^{\mathrm{Fb}}$ & $0.166^{\mathrm{Fd}}$ & $0.177^{\mathrm{F}}$ & $\underset{c}{0.026^{\mathrm{H}}}$ & $0.186^{\mathrm{Ha}}$ & $0.125^{\mathrm{H}}$ & $0.102^{\text {Hd }}$ & $\underset{\mathrm{H}}{0.110}$ \\
\hline Mean & $0.227^{\mathrm{c}}$ & $0.365^{\mathrm{a}}$ & $0.236^{\mathrm{b}}$ & $0.220^{\mathrm{d}}$ & 0.262 & $0.183^{\mathrm{c}}$ & $0.291^{\mathrm{a}}$ & $0.198^{\mathrm{b}}$ & $0.158^{\mathrm{d}}$ & 0.207 \\
\hline
\end{tabular}

Values with different superscripts are significantly different at $p<0.05$ by tukey's test for interaction between genotypes and stages

Capital letters denotes significance level of genotypes.

Small letters denotes significance level of stages

Total Nitrogen $(\%)$ in the juice of grape genotypes at different stages of berry development

\begin{tabular}{|c|c|c|c|c|c|c|c|c|c|c|}
\hline \multirow{2}{*}{ Stages } & \multicolumn{5}{|c|}{2015} & \multicolumn{5}{|c|}{2016} \\
\hline & $\begin{array}{c}\text { Green } \\
\text { stage }\end{array}$ & $\begin{array}{l}\text { Verasio } \\
\text { n stage }\end{array}$ & $\begin{array}{c}\text { Early } \\
\text { ripe }\end{array}$ & $\begin{array}{l}\text { Ripene } \\
\text { d stage }\end{array}$ & Mean & $\begin{array}{c}\text { Green } \\
\text { stage }\end{array}$ & $\begin{array}{l}\text { Verasio } \\
\text { n stage }\end{array}$ & $\begin{array}{c}\text { Early } \\
\text { ripe }\end{array}$ & $\begin{array}{l}\text { Ripene } \\
\text { d stage }\end{array}$ & Mean \\
\hline $\begin{array}{l}\text { Punjab } \\
\text { MACS } \\
\text { Purple }\end{array}$ & $0.150^{\mathrm{Ea}}$ & $0.057^{\mathrm{Eb}}$ & $0.027^{\mathrm{Ec}}$ & $0.020^{\mathrm{Ed}}$ & $0.063^{\mathrm{E}}$ & $0.117^{\mathrm{FE}}$ & $0.202^{\mathrm{DE}}$ & $0.020^{\mathrm{DE}}$ & $0_{\mathrm{Fc}}^{0.017^{\mathrm{DE}}}$ & ${ }_{\mathrm{EF}}^{0.043^{\mathrm{D}}}$ \\
\hline
\end{tabular}




\begin{tabular}{|c|c|c|c|c|c|c|c|c|c|c|}
\hline $\begin{array}{l}\text { Flame } \\
\text { Seedless }\end{array}$ & $0.120^{\mathrm{Fa}}$ & $0.027^{\mathrm{Fb}}$ & $0.013^{\mathrm{Fc}}$ & $0.017^{\mathrm{Fd}}$ & $0.044^{\mathrm{F}}$ & $0.073^{\mathrm{Fa}}$ & $0.013^{\mathrm{Fb}}$ & $0.020^{\mathrm{Fc}}$ & $0.013^{\mathrm{Fc}}$ & $0.030^{\mathrm{F}}$ \\
\hline Merlot & $0.223^{\mathrm{Ba}}$ & $0.153^{\mathrm{Bb}}$ & $0.133^{\mathrm{BC}}$ & $0.073^{\mathrm{Bd}}$ & $0.146^{\mathrm{B}}$ & $0.203^{\mathrm{Ba}}$ & $0.123^{\mathrm{Bb}}$ & $0.080^{\mathrm{Bc}}$ & $0.027^{\mathrm{Bc}}$ & $0.108^{\mathrm{B}}$ \\
\hline $\begin{array}{l}\text { Muscat } \\
\text { Hambur } \\
\text { g }\end{array}$ & $0.160^{C D}$ & $0.120_{b}^{C D}$ & $0.033^{C D}$ & $0.050^{C D}$ & $\underset{\mathrm{D}}{0.091^{\mathrm{C}}}$ & $0.130^{\mathrm{Ca}}$ & $0.113^{\mathrm{Cb}}$ & $0.033^{\mathrm{Cc}}$ & $0.013^{\mathrm{Cc}}$ & $0.073^{\mathrm{C}}$ \\
\hline $\begin{array}{l}\text { Pusa } \\
\text { Navrang }\end{array}$ & $\begin{array}{c}0.237^{\mathrm{CD}} \\
\mathrm{Ea}\end{array}$ & $\begin{array}{c}0.043^{\mathrm{CD}} \\
\mathrm{Eb}\end{array}$ & $\begin{array}{c}0.030^{\mathrm{CD}} \\
\end{array}$ & $0.013^{\mathrm{CD}}$ & $\underset{D E}{0.081^{C}}$ & $0.213^{\mathrm{Ca}}$ & $0.020^{\mathrm{Cb}}$ & $0.023^{\mathrm{Cc}}$ & $0.023^{\mathrm{Cc}}$ & $0.070^{\mathrm{C}}$ \\
\hline $\begin{array}{l}\text { Carolina } \\
\text { Black } \\
\text { Rose }\end{array}$ & $0.260^{\mathrm{Ca}}$ & $0.037^{\mathrm{Cb}}$ & $0.053^{\mathrm{Cc}}$ & $0.033^{\mathrm{Cd}}$ & $0.096^{\mathrm{C}}$ & $0.223^{\mathrm{Ca}}$ & $0.017^{\mathrm{Cb}}$ & $0.013^{\mathrm{Cc}}$ & $0.020^{\mathrm{Cc}}$ & $0.068^{C}$ \\
\hline Shiraz & $0.163^{\mathrm{Ea}}$ & $0.053^{\mathrm{Eb}}$ & $0.037^{\mathrm{Ec}}$ & $0.027^{\mathrm{Ed}}$ & $0.070^{\mathrm{E}}$ & $0.123^{\mathrm{DE}}$ & $0.033^{D E}$ & $0.017^{\mathrm{DE}}$ & $0.020^{D E}$ & $\underset{E}{0.048^{D}}$ \\
\hline H-27 & $0.120^{\mathrm{DE}}$ & $\underset{b}{0.067^{\mathrm{DE}}}$ & $\underset{c}{0.063^{\mathrm{DE}}}$ & $0.043^{\mathrm{DE}}$ & $\underset{E}{0.073^{D}}$ & $\begin{array}{c}0.077^{\mathrm{EF}} \\
{ }^{\mathrm{EF}}\end{array}$ & $0.027^{\mathrm{EF}}$ & $0.023^{E F}$ & $0.017^{\mathrm{EF}}$ & $\underset{F}{0.036^{E}}$ \\
\hline H-144 & $\underset{\mathrm{a}}{0.237^{\mathrm{CD}}}$ & $\underset{\mathrm{b}}{0.073^{\mathrm{CD}}}$ & $\underset{\mathrm{c}}{0.030^{\mathrm{CD}}}$ & $0.020^{C D}$ & $\underset{\mathrm{D}}{0.090^{\mathrm{C}}}$ & $0.130^{\mathrm{Da}}$ & $0.037^{\mathrm{Db}}$ & $0.020^{\mathrm{Dc}}$ & $0.017^{\mathrm{Dc}}$ & $0.051^{\mathrm{D}}$ \\
\hline Perlette & $0.353^{\mathrm{Aa}}$ & $0.150^{\mathrm{Ab}}$ & $0.110^{\mathrm{Ac}}$ & $0.123^{\mathrm{Ad}}$ & $0.184^{\mathrm{A}}$ & $0.267^{\mathrm{aa}}$ & $0.117^{\mathrm{ab}}$ & $0.057^{\mathrm{ac}}$ & $0.077^{\mathrm{ac}}$ & $0.129^{\mathrm{A}}$ \\
\hline Mean & $0.202^{\mathrm{a}}$ & $0.078^{b}$ & $0.053^{\mathrm{c}}$ & $0.042^{\mathrm{d}}$ & 0.094 & $0.156^{\mathrm{a}}$ & $0.052^{b}$ & $0.031^{\mathrm{c}}$ & $0.024^{\mathrm{c}}$ & 0.065 \\
\hline
\end{tabular}

Values with different superscripts are significantly different at $p<0.05$ by tukey's test for interaction between genotypes and stages

Capital letters denotes significance level of genotypes.

Small letters denotes significance level of stages

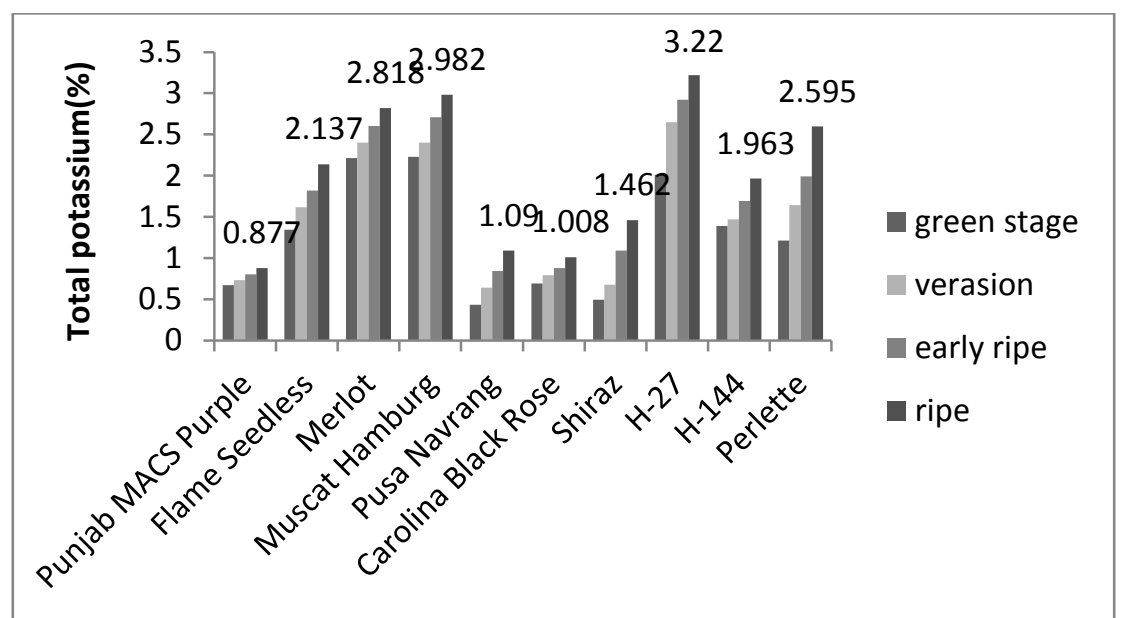

Fig1:-Overall genotype $\times$ stage interaction of total potassium in grape berry skin (value over the graphs is the interaction of pooled data and only maximum values are indicated) 


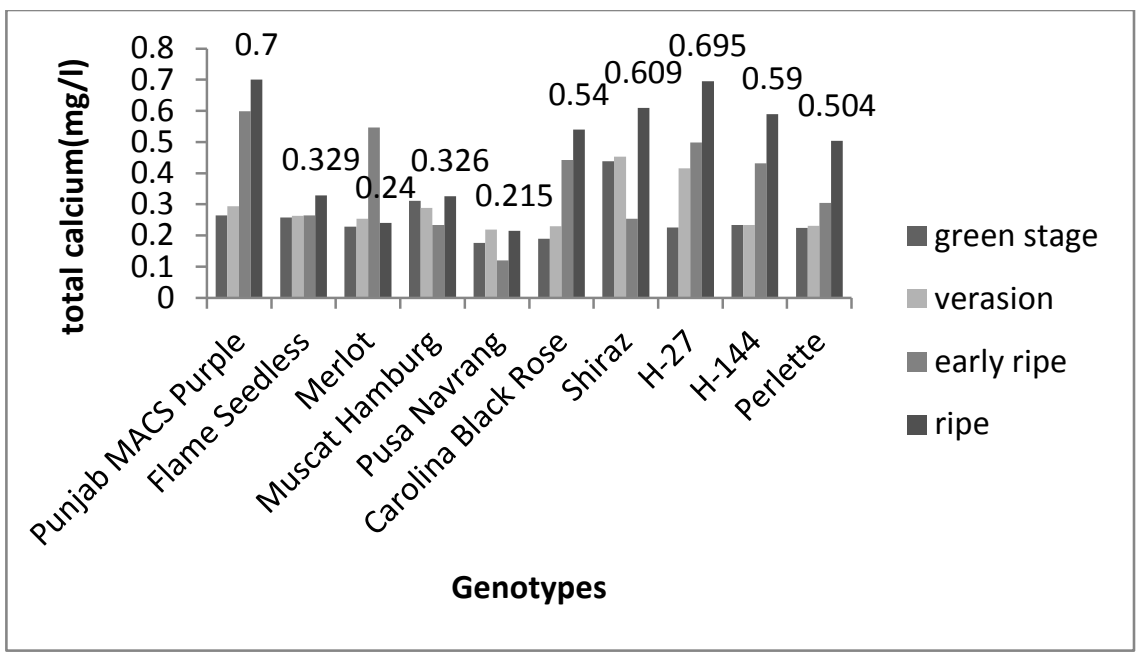

Fig 2:-Overall genotype $\times$ stage interaction of total calcium in grape berry skin (value over the graphs is the interaction of pooled data and only maximum values are indicated

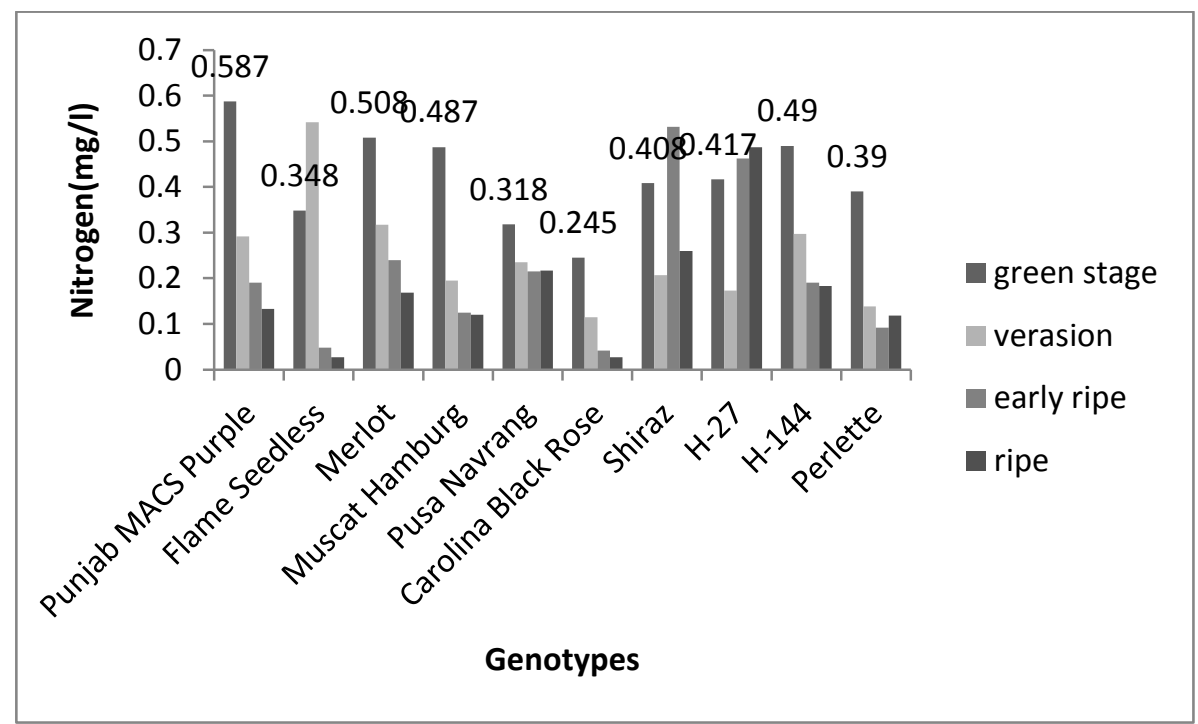

Fig 3:-Overall genotype $\times$ stage interaction of total nitrogen in grape berry skin (value over the graphs is the interaction of pooled data and only maximum values are indicated

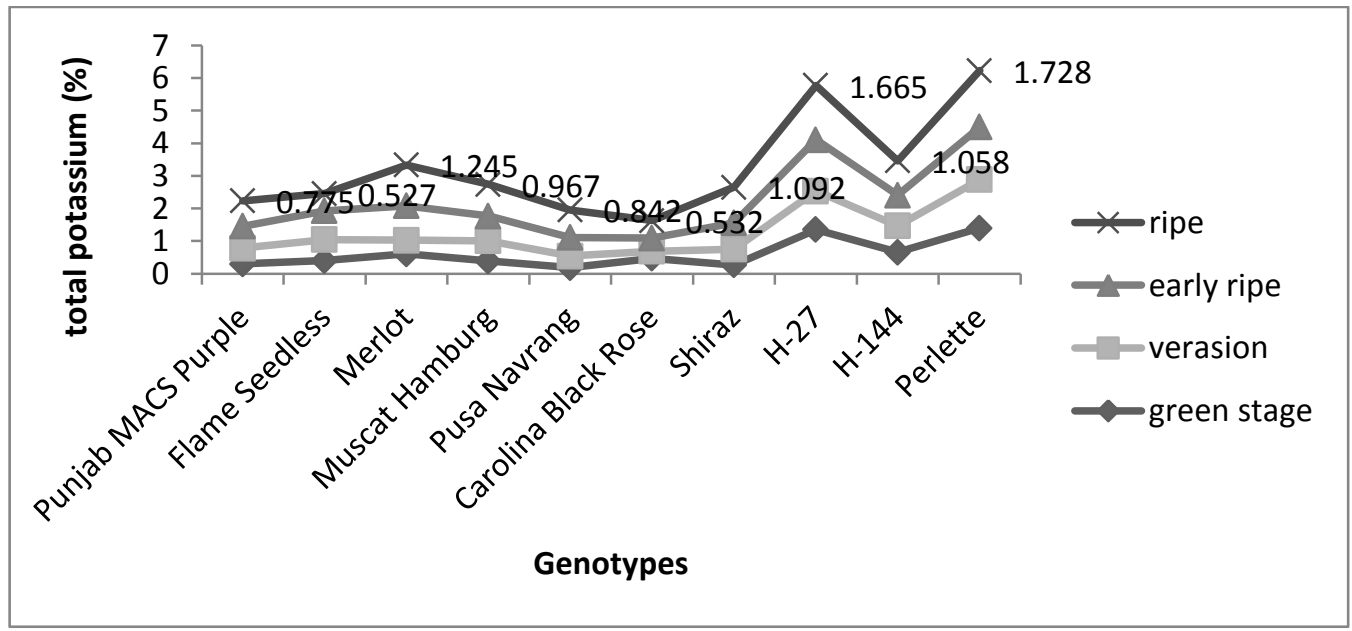


Fig 4:-Overall genotype $\times$ stage interaction of total potassium in grape juice (value over the graphs is the interaction of pooled data and only maximum values are indicated

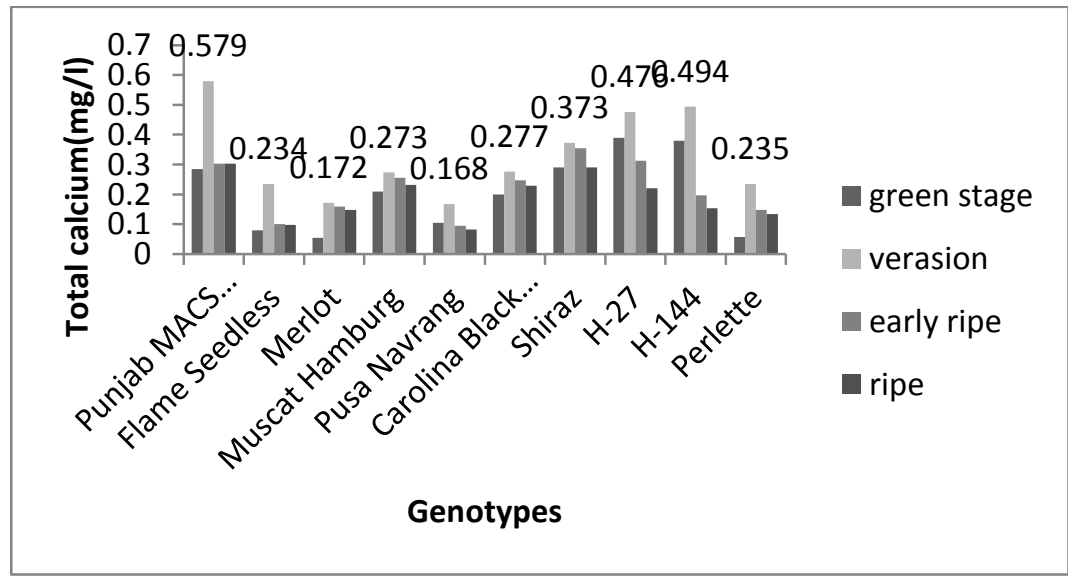

Fig 5:-Overall genotype $\times$ stage interaction of total calcium in grape juice

(value over the graphs is the interaction of pooled data and only maximum values are indicated

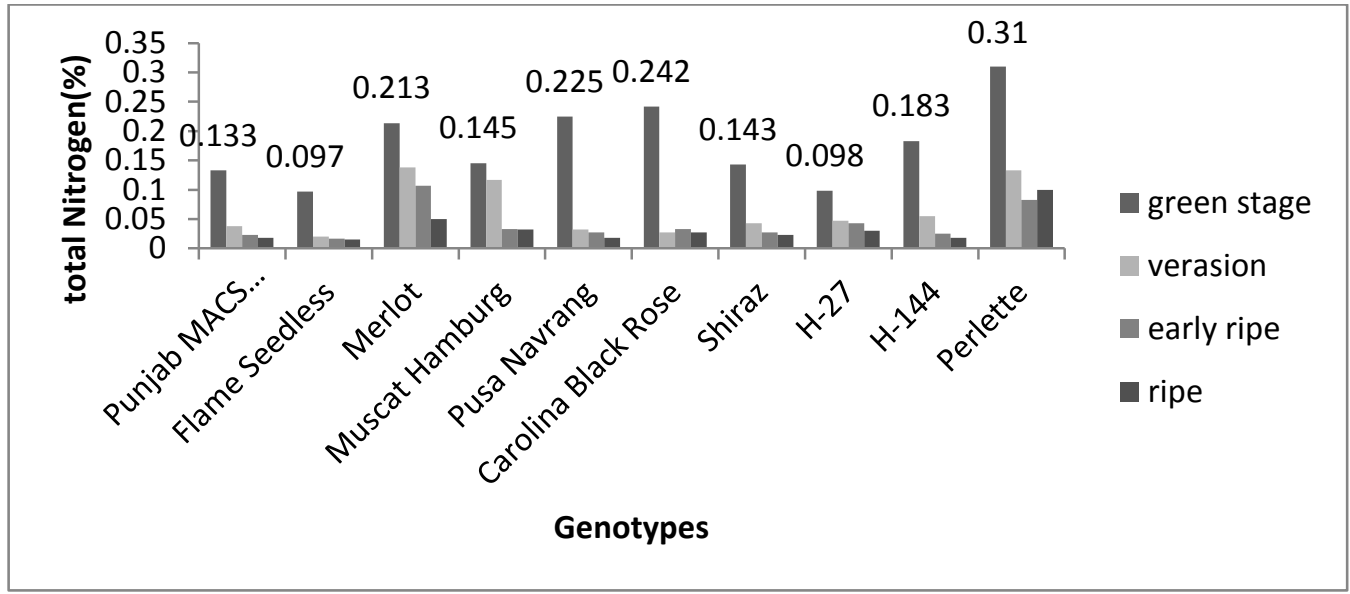

Fig 6:-Overall genotype $\times$ stage interaction of total nitrogen in grape juice

(value over the graphs is the interaction of pooled data and only maximum values are indicated

\section{Refrences:-}

1. A O A C. 1990 Methods of analysis. $10^{\text {th }}$ Edition, Washington DC, USA.

2. Blouin, J; Cruege, J; 2003. Analyse et Composition des Vins: Comprendre le Vin, Editions La Vigne, Dunod, Paris, France Pp. 304

3. Bradfield, E. G; Spincer, D. J; 1965. Leaf analysis as a guide to the nutrition of fruit crops-determination of magnesium, zinc and copper by atomic absorption spectroscopy. J. Sci. Food Agric.16(1): 33-38

4. Cabanne, C; Doneche, B; 2003. Calcium accumulation and redistribution during the development of the grape berry. Vitis 42: 19-21.

5. Chardonnet, C; Doneche, B; 1995. Relation entre la teneur en calcium et al resistance a la digestion enzymatique du tissu pelliculaire au cours de la maturation du raisin. Vitis 34: 95-98

6. Conde, C. P; Silva, N; Fontes, A. C. P; Dias, R. M; Sousa, M. J; 2007. Biochemical changes throughout grape berry development and fruit and wine quality. Food 1: 1-22

7. Cosgrove, D. J ; 1997. Relaxation in a high stress environment: the molecular bases of extensible cell walls and cell enlargement. Plant Cell 9:1031-1041

8. Etchebarne, F; Ojeda, H; Deloire, A; 2009. Influence of water status on mineral composition of berries in 'Grenache Noir' (Vitis vinifera L.). Vitis 48: 63-68

9. Greenspan, M. D; Schultz, H. R; Matthews, M. A; 1996. Field evaluation of water transport in grape berries during water deficits. Physiol. Plant. 97: 55-62 
10. Hager, A; Menzel, H; Krauss, A ;1971. Versuche und hypothese zur primarwirkung des auxins beim shtrekungswachstum. Planta 100:47-75

11. Huang, X; Huang, H; 2001. Early post-verasion growth in grapes: evidence for a two-step mode of berry enlargement. Aust. J. Grape Wine Res. 7: 132-136

12. Lang, A ; Thorpe, M. R; 1989. Xylem, phloem and transpiration flows in a grape: Application of a technique for measuring the volume of attached fruits to high resolution using Archimedes' Principle. J. Exp. Bot 40: 10691078

13. Mullins, M. G; Bouquet, A; Williams, L. E; 1996. Biology of the grapevine. Cambridge University Press, Cambridge

14. Rogiers, S. Y; Greer, D. H; Hatfield, J. M; Orchard, B .A; Kelle, M; 2006 Mineral sinks within ripening grape berries (Vitis vinifera L.). Vitis 45 (3):115-123

15. Rogiers, S. Y; Smith, J .S; White, R; Keller, M; Holzapfel, B. P; Virgona ,J .M; 2001.Vascular function in berries of Vitis vinifera (L) cv. Shiraz. Aust. J. Grape Wine Res 7:47-51.

16. Welch, R. M. 1986. Effects of nutrient deficiencies on seed production and quality. Ad Plant Nutri. 2: 205-247. 